\title{
PREX2 wt Allele
}

National Cancer Institute

\section{Source}

National Cancer Institute. PREX2 wt Allele. NCI Thesaurus. Code C102518.

Human PREX2 wild-type allele is located in the vicinity of 8q13.2 and is approximately 285

$\mathrm{kb}$ in length. This allele, which encodes phosphatidylinositol 3,4,5-trisphosphate-

dependent Rac exchanger 2 protein, plays a role in the regulation of small GT Pase-

dependent signaling. 